\title{
Sosialisasi Konservasi Hutan Mangrove Berbasis Syariah kepada Masyarakat Pesisir di Gampong Kuala Bubon Kecamatan Samatiga Kabupaten Aceh Barat Propinsi Aceh
}

\section{The Socialization of Mangrove Forest Conservation Based on Sharia to Coastal Community in the Kuala Bubon Village Samatiga District West Aceh Regency, Province of Aceh}

\author{
Mohamad Gazali ${ }^{1}$, Supriadi², Muhammad Nurdin², Muhammad Ilham² \\ ${ }^{1}$ Prodi Sumberdaya Akuatik Fakultas Perikanan dan IImu Kelautan Universitas Teuku Umar \\ ${ }^{2}$ Prodi Perikanan Fakultas Perikanan dan IImu Kelautan Universitas Teuku Umar \\ *Korespondensi :mohamadgazali@utu.ac.id
}

\begin{abstract}
ABSTRAK
Kawasan pesisir Desa Kuala Bubon Kecamatan Samatiga Kabupaten Aceh Barat terdapat beberapa jenis mangrove yaitu Rhizoporastylosa, Rhizoporaapiculata BI dan Nypa fruticans. Aceh terkenal dengan julukan "Serambi Mekkah" yang merupakan satu-satunya propinsi di Indonesia yang menerapkan syariah islam kepada masyarakatnya. Aturan pemerintah daerah dirancang berdasarkan hokum syariah islam. Aturan yang mengikat di Wilayah Aceh disebut Qanun Aceh. Oleh karena itu, perlu dilakukan suatu pendekatan untuk mengubah pola piker (mindset) secara bertahap untuk menjaga ekosistem mangrove dengan memperkenalkan melalui media dakwah dan pendekatan aksi nyata. Permasalahan utama yang dihadapi masyarakat pesisir Desa Kuala Bubon adalah kurangnya kesadaran dan pemahaman yang luas tentang pengelolaan hutan mangrove secara berkelanjutan.Selain itu, Pelibatan dan sosialisasi tentang konservasi hutanmangrove secara berkala kepada masyarakat pesisir masih sangat minim dilakukan oleh pihak terkait.Tujuan kegiatan pengabdian kepada masyarakat ini adalah untuk memberikan pemahaman dan pengetahuan tentang konservasi hutan mangrove dengan melibatkan tokoh agama dan masyarakat pesisir Desa Kuala Bubon. Kegiatan pengabdian masyarakat yang telah dilakukan meliputi kegiatan penyemaian bibit mangrove yang diperoleh di alam. Selanjutnya, dengan melibatkan masyarakat kami melakukan kegiatan dakwah di mesjid Nurul Iman yang dilakukan pada bulan suci ramadhan. Untuk meningkatkan pengetahuan tentang konservasi mangrove, kami melakukan kegiatan penyuluhan yang dihadiri oleh aparatur desa dan masyarakat pesisir. Berdasarkan hasil musyawarah, kami melakukan aksi penanaman bibit mangrove di sekitar mesjid nurul iman sebagai sabuk hijau(green belt). Selain itu, kami juga memberikan sedekah jariah kepada pengurus mesjid Nurul Iman untuk pengembangan Mesjid Nurul Iman sebagai wadah dakwah untuk masyarakat Desa Kuala Bubon.
\end{abstract}

Kata kunci : Konservasi, Hutan Mangrove, Syariah, Sosialisasi

\begin{abstract}
The coastal Area of Kuala Bubon subdistrict, Samatiga District, West Aceh regency, Aceh Province have several mangrove species including Rhizoporastylosa, RhizoporaapiculataBI andNypa fruticans. Aceh is popular with epithet "Serambi Mekkah" that is the only province in Indonesia that stipulated sharia to the Aceh community. The local goverment regulation was designed according to islamic sharia. Dependent rule in Aceh Area is named Qanun Aceh. Therefore, it is neccessary to undertaken a approach to change gradually their mindset for keeping mangrove ecosystem through dakwah media and real action. The main problem in Kuala Bubon's community are lack of awareness and wide understanding regarding management of mangrove forest sustainable. Otherwise, the involvement and socialization of mangrove conservation with periodically with coastal community is still poor that undertaken by stakeholder. The purpose of this program is to give undertanding and knowledge regarding forest mangrove conservation that involved cleric and community figure. These programs that is conducted including seedings from natural. Subsequently, we involved local community in da'wah that is conducted in Ramadhan Month. Forincreasing the knowledge about mangrove conservation, we conducted extension activity that attended by local government and coastal community. According to deliberation, we conducted the planting of mangrove seeds in nearby Nurul Iman mosque as green belt. Otherwise, we also give them sedekah to Nurul Iman
\end{abstract}


organizer for development of Nurul Iman Mosque as da'wah media for Kuala Bubon's community.

Keywords : Conservation, Mangrove Forest, Sharia, Socialization

\section{PENDAHULUAN \\ Latar Belakang}

Indonesia merupakan negara kepulauan terbesar di dunia memiliki 17.508 pulaudengan garispantaisepanjang $\pm 81.000 \mathrm{~km}$. Negara ini memiliki potensi sumberdaya pesisir dan laut yang sangat besar (Bengen, 2001a). Salah satu potensi sumberdaya pesisir dan laut adalah hutan mangrove. Negara ini memilikihutan mangrove yang sangat besar yaitu hampir $25 \%$ hutan mangrove di dunia tersebar \pm 3,6 juta ha berada di Kepulauan Indonesia baik di pulau besar maupun pulau-pulau kecilnya (KEMENHUT, 2012).Luasan hutan mangrove sekitar75\% yang beradadi Kawasan Asia Tenggara tumbuh di Indonesia dengan kelimpahan yang tinggi baik dari segi kuantitas area $\left( \pm 42.550 \mathrm{~km}^{2}\right)$ maupun jumlah spesies ( \pm 45 spesies)(Spalding et al., 1997). Luasanhutan mangrove terbesar berada di Provinsi Papua(FAO, 2007).

Salah satu komponen ekosistem pesisir dan laut adalah hutan mangrove. Hutanmangrove mempunyai fungsi ekologi yang penting, seperti peredam gelombang dan angin, pelindung pantai dari abrasi, penahan lumpur dan penangkap sedimen yangdiangkut oleh aliran air, sebagai daerah asuhan dan tempat mencari makan sertamerupakan tempat pemijahan bermacam-macam biota perairan, sebagai penyuburperairan karena menghasilkan detritus dari seresah daun yang diuraikan oleh bakteri menjadi zat hara (Bengen, 2001b). Selain itu produk dari mangrove dapat dihasilkan baiksecara langsung ataupun tidak langsung sebagai kayu bakar, bahan bangunan, keperluanrumah tangga/perkakas, bahan kertas,bahan tekstil, alat perikanan, pupuk pertanian danobat-obatan (Nooret al., 1999). Irawan (2005) melaporkan bahwa keberadaan hutan mangrove dapat memperkecil resiko akibat dampak tsunami di PropinsiNangroe Aceh Darusalam. Daerah-daerah yang memiliki front zonasi mangrovekerusakannya tidak terlalu parah jika dibandingkan dengan daerah yang tidak memilikifront hutan mangrove.Adanya perubahan lingkungan ekosistem wilayah pesisir laut secara tidaklangsung akan mempengaruhi sistem komunitas yang berada di dalamnya (Irawan, 2003),termasuk terhadap keanekaragaman jenis dan struktur komunitas yang berada dalamekosistem tersebut.

Berdasarkan hasil observasi bahwa di kawasan pesisir Desa Kuala Bubon Kecamatan Samatiga Kabupaten Aceh Barat Provinsi Aceh terdapat beberapa jenis mangrove yaitu Rhizoporastylosa, Rhizoporaapiculata Bl dan Nypa fruticans. Aceh terkenal dengan julukan "Serambi Mekkah" merupakan satu-satunya propinsi di Indonesia yang menerapkan syariah islam kepada masyarakatnya. Aturan pemerintah daerah dirancang berdasarkan hokum syariah islam. Aturan yang mengikat di Wilayah Aceh disebut Qanun Aceh. Oleh karena itu, perlu adanya pendekatan untuk mengubah pola piker (mindset) secara bertahap untuk menjaga ekosistem mangrove dengan memperkenalkan melalui media dakwah dan pendekatan aksi nyata. Hal ini menjadi inisiatif bagi peneliti untuk melakukan kegiatan pengabdian kepada masyarakat yaitu Sosialisasi Konservasi Hutan Mangrove Berbasis Syariah kepada Badan Kemakmuran Mesjid (BKM) Nurul Iman Samatiga Kabupaten Aceh Barat Provinsi Aceh. Mitra dalam kegiatan Program Pengabdian Kepada Masyarakat adalah $\mathrm{Ba}$ dan Kemakmuran 
Masjid (BKM) Nurul Iman di Desa Kuala Bubon yang berdekatan langsung dengan kawasan pesisir hutan mangrove.

\section{Permasalahan}

Gempa bumi dan tsunami pada Tahun2004, hampir 100\% hutan mangrove di Pantai Barat Aceh mengalami kerusakan total. Jika luas kerusakan hutanmangrove sekitar 105.260 ha, maka kedepan memerlukan sumber daya yangcukup besar dan kerja keras untuk mengembalikan hutan mangrove yang rusaktersebut. Bahkan Aceh dengan panjang garis pantai sekitar $2.467 \mathrm{~km}$ memerlukanmangrove lebih dari 200.000 ha sebagai buffer zone atau greenbelt yang berfungsi untuk mencegah erosi dan abrasi serta mengurangi energi gelombang.

Ditinjau dari potensi sumberdaya bahwa hutan mangrove yang ada di AcehBarat masih memiliki potensi untuk berkembang menjadi suatu kawasan hutanmangrove. Hal ini dapat terwujud apabila terdapat peran serta masyarakat dalammelestarikan hutan mangrove. Peranan peneliti dalam menggerakkanmasyarakat ke arah yang lebih baik akan memberikan dampak positif dalammencapai keberlanjutan sumberdaya hutan mangrove yang ada di wilayah pesisirAceh Barat tepatnya di Desa Kuala Bubon.

Kurangnya kesadaran dan pemahaman yang luas tentang pengelolaan hutan mangrove secara berkelanjutan adalah permasalahan utama yang dihadapimasyarakat pesisir Desa Kuala Bubon.Selain itu, Pelibatan dan sosialisasi tentang konservasi hutanmangrove secara berkala kepada masyarakat pesisir masih sangat minim dilakukan oleh pihak terkait.Banyak proyek penanaman bibit mangrovecenderung bersifat money orientedyang dilakukan olehsegelintir orangsehinggakadangkala proyek konservasi lingkungan dilakukan dengan cara sembarangantanam tanpa memperhatikan metode penanaman bibit mangove yang benar. Hal inilah menjadi inisiatif kami untuk melaksanakan Kegiatan sosialisasi Konservasi hutan mangrove berbasis syariah kepada Badan KemakmuranMesjid (BKM) di Desa Kuala Bubon Kabupaten Aceh Barat Propinsi Aceh.

\section{Tujuan Kegiatan}

Tujuan kegiatan pengabdian kepada masyarakat ini adalah untuk memberikan pemahaman dan pengetahuan tentang konservasi hutan mangrove dengan melibatkan tokoh agama dan masyarakat pesisir Desa Kuala Bubon. Output dari kegiatan ini adalah bagaimana ke depan masyarakat pesisir Desa Kuala Bubon mampu memanfaatkan ekosistem hutan mangrove secara berkelanjutan. 


\section{METODELOGI}

\section{Waktu dan Lokasi}

Kegiatan pengabdian kepada masyarakat dilaksanakan pada bulan Juni 2017 yang bertempat di Desa Kuala Bubon Kecamatan Samatiga Kabupaten Aceh Barat Propinsi Aceh (Gambar 1).

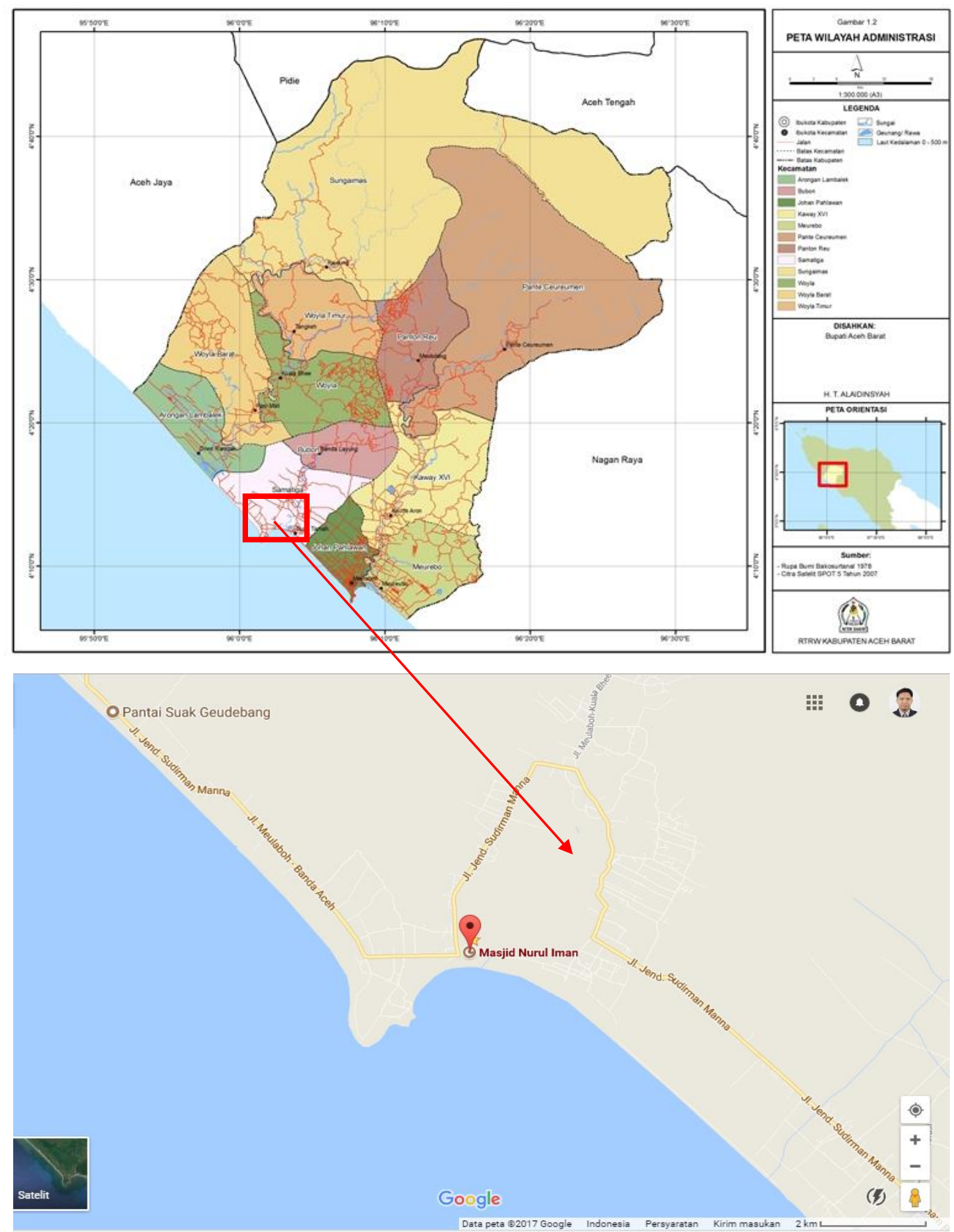

Gambar 1. Peta Lokasi Kegiatan Pengabdian kepada Masyarakat

Sumber : (BPS Kabupaten Aceh Barat, 2014 dan Google Maps 2017) 


\section{Metode}

Metode pelaksanaan dengan menggunakan teknik penyuluhan secara langsung yaitu melakukan dakwah tentang konservasi hutan mangrove di mesjid, penyuluhan teknik penanaman mangrove di Balai Desa dan Aksi penanaman mangrove di pesisir kawasan hutan mangrove. Bentuk sosialisasi/dakwah konservasi hutanmangrove tersebut sangat tepat untuk menumbuhkan kesadaran masyarakat pesisir dan generasi muda dalam mempertahankan kawasan mangrove yang mempunyai banyak manfaat bagi kehidupan masyarakat yang berada di Desa Kuala Bubon.Adapun langkahlangkah sosialisasi atau dakwah yang telah berjalan adalah sebagai berikut:

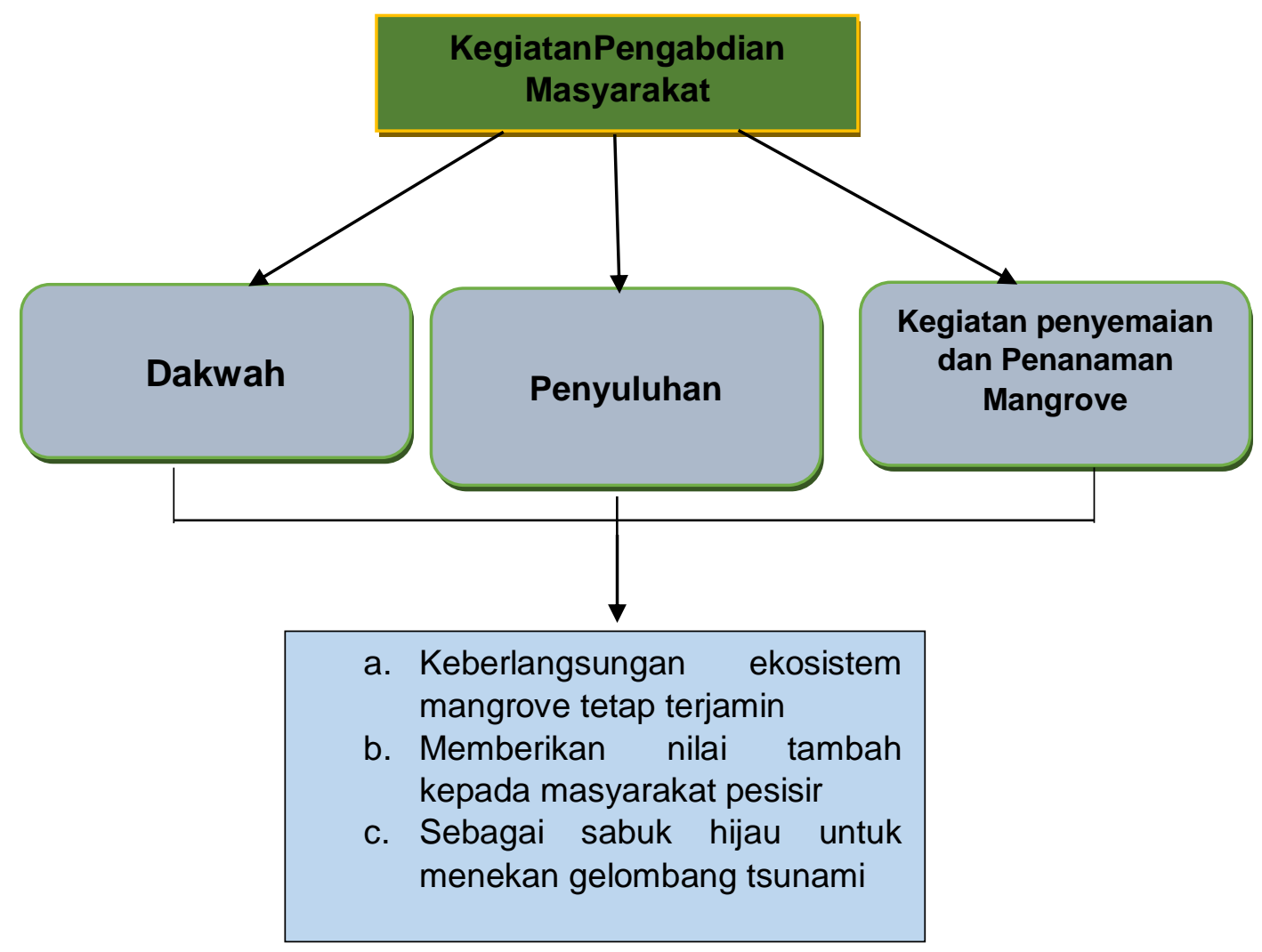

\section{HASIL DAN PEMBAHASAN}

Penyemaian Bibit Mangrove

Pada langkah awal, kami melakukan kegiatan penyemaian bibit mangrove yang dilakukan pada pagi hari bersama masyarakat pesisir. Untuk kebutuhan penyemaian bibit mangrove yaitu dengan mencari bibit mangrove yang sudah tua atau buah yang telah jatuh. Kemudian dipindahkan ke dalam wadah polibag .Bibit mangrove tersebut diletakkan di daerah yang terkena dengan pasang surut air laut.Hal ini dilakukan agar bibit mangrove tersebut selalu terkena air sehingga meminimalisir tingkat kematian.

Penyemaian bibit mangrove ini dilakukan bertujuan untuk persiapan pelaksanaan penanaman mangrove di Pesisir Desa Kuala Bubon. Kegiatan ini mengupayakan agar pertumbuhan mangrove di kawasan pesisir tersebut semakin baik melalui teknik penanaman yang sesuai dengan prosedur (Gambar 1). 


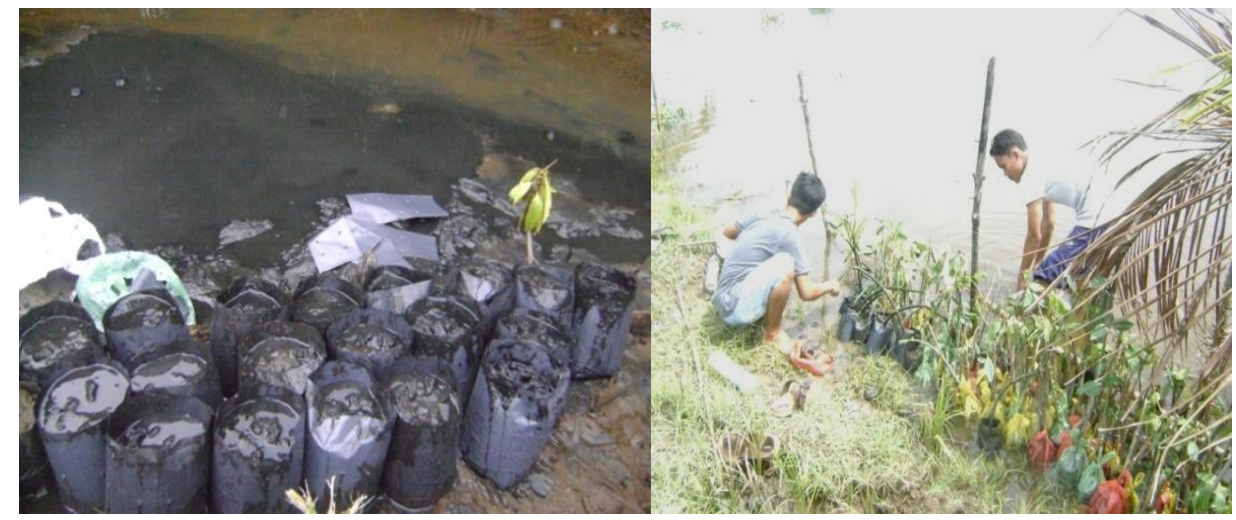

Gambar 1. Penyemaian Bibit mangrove di Desa Kuala Bubon

Sumber : (Dokumentasi Pengabdian kepada Masyarakat, 2017)

\section{Kegiatan Dakwah di Masjid Nurul Iman}

Kami melakukan Dakwah/ceramah tentang lingkungan pesisir khususnya ekosistem mangrove di Masjid Nurul ImanDesa Kuala Bubon yang dimulai setelah shalat magrib. Konteks dakwah berkaitan hubungan manusia dengan Sang Pencipta (Allah SWT), hubungan sesama manusia, dan Hubungan dengan alam khususnya hutan mangrove. Menurut kami, metode ini sangat efektif untuk kegiatan sosialisasi melalui kegiatan dakwah kepada masyarakat sehingga memiliki pengetahuan dan pemahaman yang baik terkait pelestarian hutan mangrove.

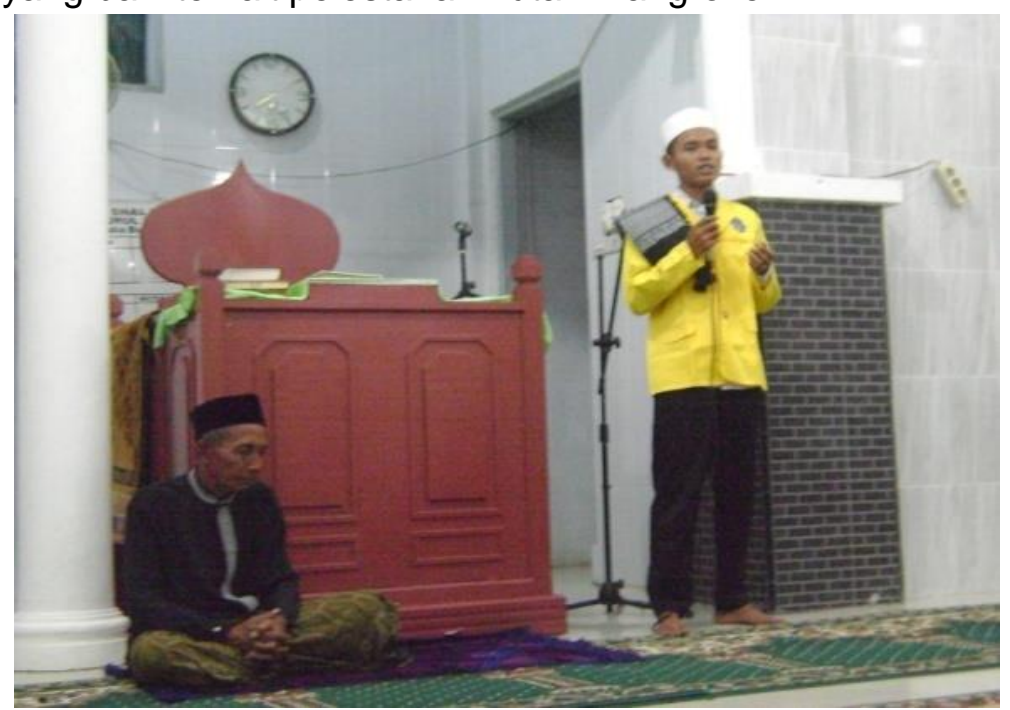

Gambar 2. Dakwah di Masjid Nurul Iman Kuala Bubon Sumber : (Dokumentasi Pengabdian kepadaMasyarakat, 2017)

\section{Penyuluhan Konservasi Mangrove}

Kami melaksanakan kegiatan penyuluhan tentang pengelolaan mangrove secara lestari kepada masyarakat pesisir Desa Kuala Bubon. Kegiatan tersebut melibatkan mahasiswa Fakultas Perikanan dan IImu Kelautan Universitas Teuku Umar. Tujuan dari kegiatan tersebut adalahuntuk memberikan bimbingan teknik (BIMTEK) serta pengetahuan tentang pengelolaan ekosistem mangrove secara berkelanjutan. Kegiatan tersebut mendapat dukungan penuh dari aparatur desa, tokoh masyarakat, 
tokoh pemuda dan tokoh agama. Kegiatan tersebut diharapkan member dampak positif bagi masyarakat Pesisir (Gambar 3).

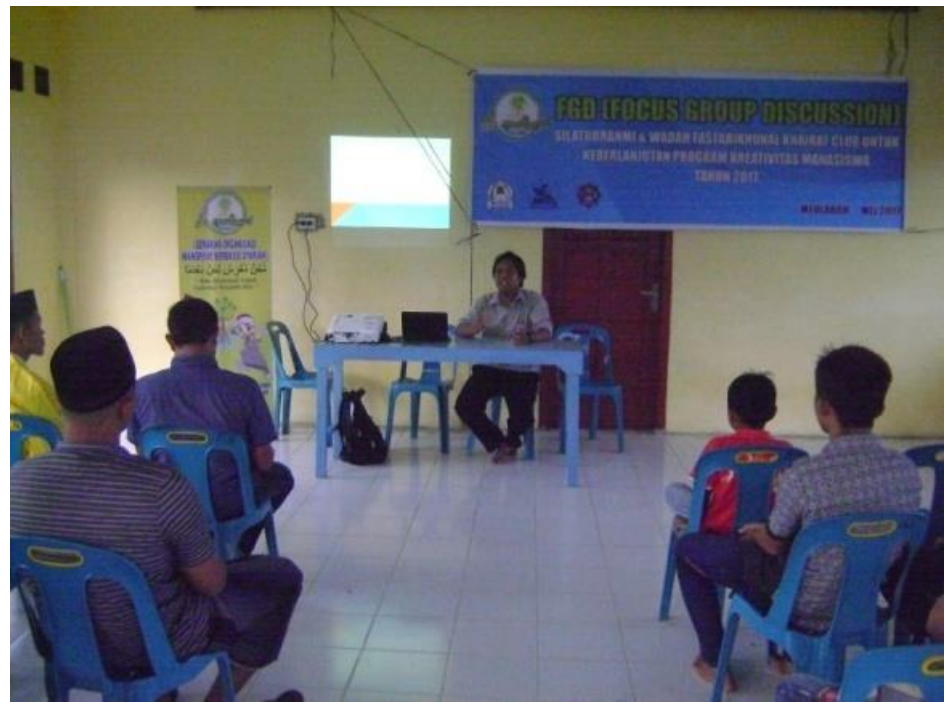

Gambar 5. Kegiatan Penyuluhan

Sumber : (Dokumentasi Pengabdian Masyarakat, 2017)

\section{Aksi Penanaman Mangrove}

Aksi penanaman bibit mangrove dilakukan bersama masyarakat pesisir Desa Kuala Bubon. Penanaman bibit dimulai pada sore harisesuai dengan hasil musyawarah masyarakat pesisir dimana pada sore hari mereka sudah selesai melakukan pekerjaan rutinitas. Jumlah bibit mangrove yang kami tanam bersama masyarakat sebanyak 300 batang. Aksi penanaman mangrove dilakukan pada sore hari dikarenakan perairan tersebut mengalami pasang surut pada sore hari itu jadi sangat cocok untuk dilakukan penanaman mangrove dengan masyarakat lokal.

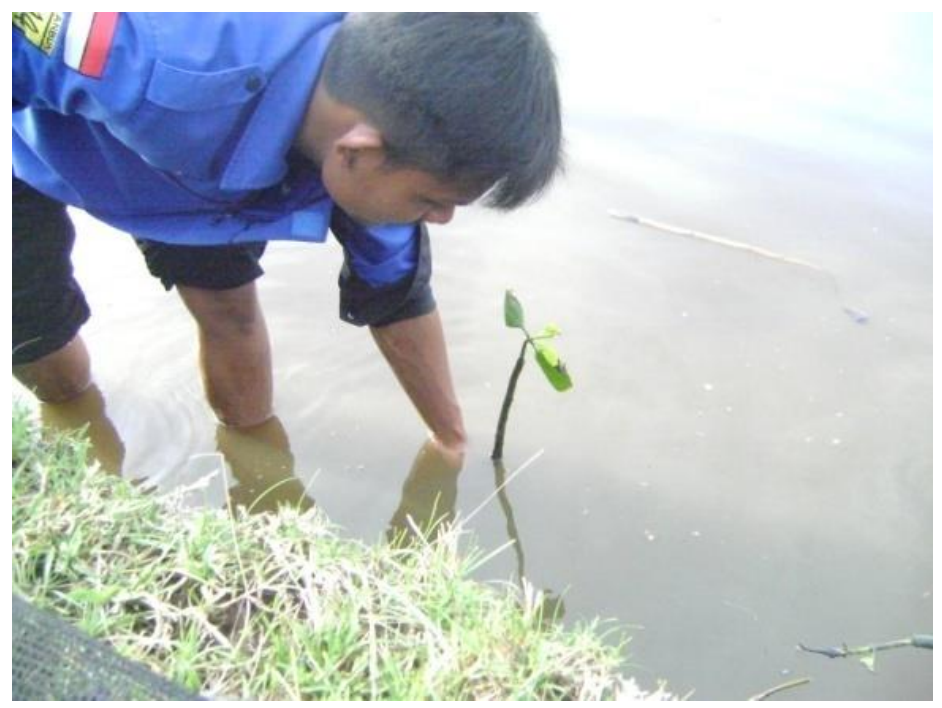

Gambar 6. Penanaman Mangrove di kawasan Kuala Bubon Sumber : (DokumentasiPengabdianMasyarakat, 2017) 


\section{Pemberian Sedekah Jariah kepada Mesjid Nurul Iman}

Kami memberikan sedekah jariah kepada mesjid Nurul Iman sebagai bentuk kepedulian kepada mesjid yang merupakan sarana dakwah umat islam (Gambar 7). Kami berusaha dengan keikhlasan dan keteguhan hati memberikan sebagian rezeki untuk pengembangan mesjid Nurul Iman yang berdekatan dengan kawasan hutan mangrove. Pada sebelum dan sesudah bulan suci ramadhan kami melaksanakan dakwah yang berisi tentang pentingnya menjaga lingkungan dalam konteks islam. Kami menyampaikan beberapa ayat al-Qur'an yang berkaitan dengan pentingnya menjaga lingkungan sepertinya yang termaktub dalam surat Ar-Rum ayat 41 berikut ini

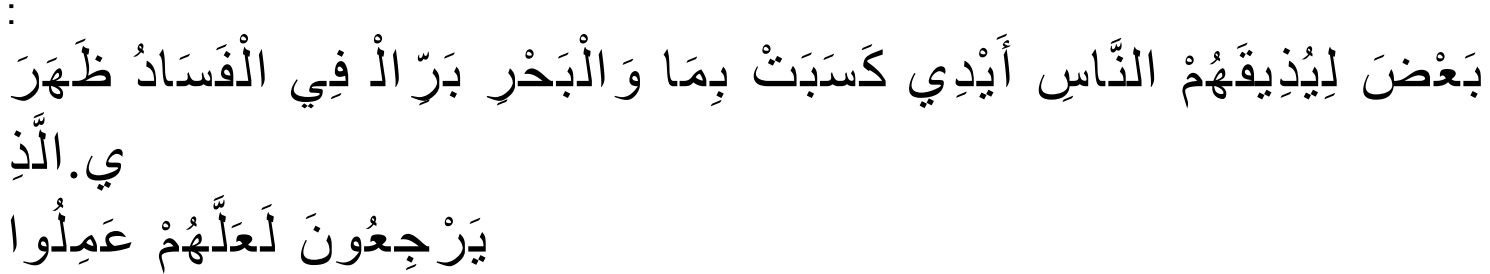
Artinya :

Telah nampak kerusakan di darat dan di laut disebabkan karena perbuatantangan manusia, supaya Allah merasakan kepada mereka sebahagian dari(akibat) perbuatan mereka, agar mereka kembali (ke jalan yang benar) (SurahArRum : 41).

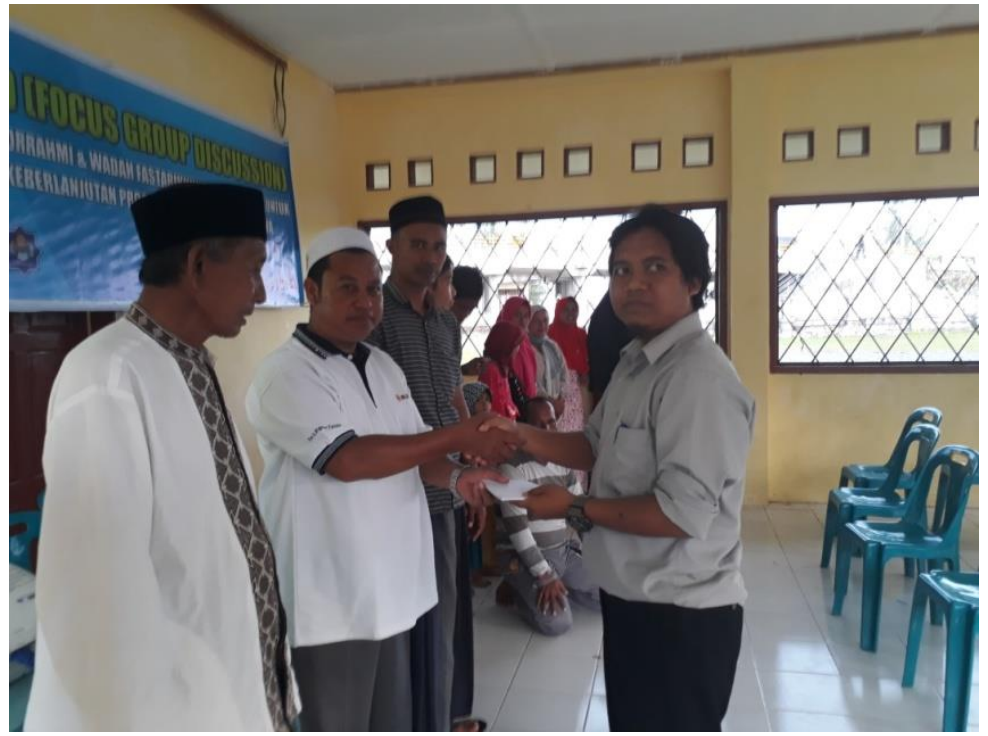

Gambar 7. Pemberian sedekah jariah kepada DKM Mesjid Nurul Iman

Sumber : (DokumentasiPengabdianMasyarakat, 2017)

\section{PENUTUP}

\section{Kesimpulan}

Berdasarkan hasil dan pembahasan maka dapat disimpulkan bahwa kegiatan Sosialisasi Konservasi Hutan Mangrove Berbasis Syariah kepada Masyarakat Pesisir di Gampong Kuala Bubon Kecamatan Samatiga Kabupaten Aceh Barat Propinsi Aceh melibatkan mahasiswa Fakultas Perikanan dan Ilmu Kelautan Universitas Teuku Umar dan masyarakat pesisir Desa Kuala Bubon. Dalam rangkaian kegiatan meliputi penyemaian bibit mangrove, kegiatan dakwah, penyuluhan, aksi penanaman bibit mangrove dan pemberian sedekah jariah. Kegiatan tersebut berjalan dengan lancar 
sesuai harapan berkat dukungan penuh dari seluruh elemen masyarakat Desa Kuala Bubon.

\section{DAFTAR PUSTAKA}

Bengen DG. 2001a. Sinopsis Ekosistem dan Sumberdaya Alam Pesisir dan Laut. Pusat

Kajian Sumberdaya Pesisir dan Laut, Institut Pertanian Bogor

Bengen DG. 2001b. Pengenalan dan Pengelolaan Ekosistem Mangrove. Pusat Kajian Sumberdaya Pesisir dan Laut, Institut Pertanian Bogor

FAO. 2007. The world's mangroves 1980 - 2005. FAO Publisher Rome. Italy

KEMENHUT. 2012. Data danInformasi Mangrove SempadanPantai. Jakarta.

Irawan B. 2005. Kondisi Vegetasi Mangrove di Banda Aceh, Aceh Besar dan Meulaboh Propinsi NAD Pasca Tsunami. Laporan Peninjauan Wilayah Pesisir Propinsi NAD Pasca Tsunami, Kementrian Lingkungan Hidup-GTZ.

Irawan B. 2003. Kondisi Vegetasi Mangrove di Pulau Bintan, Kabupaten Kepulauan Riau dalam Burhanuddin dkk (ed.) Kondisi Ekosistem Pesisir PulauBintan. Pusriswilnon-BRKP-Dep. KP. ISBN 979-98165-0-5; hlm 50-58.

Noor YL,Khazali M dan Suryadipura INN. 1999. Panduan Pengenalan Mangrove di Indonesia. Bogor : Wetland International - Indonesia Programme.

Spalding M, Blasco F, Field C. 1997. The World Mangrove Atlas. The International Society for Mangrove Ecosystem (ISME). Okinawa. Japan 178 pp. 